\title{
INDÍTÓMOTOROK KEFEKOPÁSÁNAK MÉRÉSE PRECÍZIÓS OPTIKAI MÓDSZEREKKEL I.
}

\author{
Paripás Béla \\ egyetemi tanár, Miskolci Egyetem, Fizikai és Elektrotechnikai Intézet \\ 3515 Miskolc, Miskolc-Egyetemváros, e-mail: fizpari@uni-miskolc.hu \\ Béres Miklós \\ mérnöktanár, Miskolci Egyetem, Fizikai és Elektrotechnikai Intézet \\ 3515 Miskolc, Miskolc-Egyetemváros, e-mail: mechbere@uni-miskolc.hu \\ Csörgö Ádám \\ fejlesztömérnök, SEGA Hungary Kft., Miskolc \\ 3526 Miskolc, Robert Bosch Park 3.e-mail: Adam.Csorgo@SEG-automotive.com
}

\begin{abstract}
Absztrakt
Az inditómotorok tartóssági tesztjének fontos eleme a kefekopás mérése, amelyet a motor belsejében, a házán lévö furaton keresztül kell elvégezni. A jelenlegi mechanikus mérések pontossága 0,1mm körüli, amelyen nagyságrendeket szeretnénk javitani. Az elérhetö optikai módszerek közül erre a feladatra a konfokális távolságérzékelös és a lézeres háromszögeléses módszerek lehetnek alkalmasak. Mivel a méröfej csak a mérés idejére maradhat a motoron, ennek preciziós pontosságú visszahelyezését az egymást követő mérésekre meg kell oldani. Az ezt biztositó speciális méröfej tartó megtervezése e program legkényesebb eleme volt. Cikkünk elsö részében egy konfokális - Omron ZW-S40 méröfejes - teszt eredményét is ismertetjük. Az 50 ezer inditásos teszt során az eszköz hibátlanul müködött. Igen sok (legalább száz) visszarakást követö pozíció mérés alapján állítjuk, hogy a garantált visszarakási pontosság 2-3 $\mu \mathrm{m}$, a hömérsékleti bizonytalanságok által okozott hiba $5 \mu \mathrm{m}$ alatt tartható (tervezett idökeretben történö mérés során).
\end{abstract}

Kulcsszavak: inditómotor teszt, kefekopás mérés, konfokális távolságérzékelés

\begin{abstract}
An important element of the durability test of starter motors is the measurement of brush wear, which must be performed inside the motor through a borehole in the housing. The accuracy of the current mechanical measurements is around $0.1 \mathrm{~mm}$, on which we would like to improve orders of magnitude. Out of the available optical methods, the confocal distance sensor and the laser triangulation methods can be suitable for this task. Since the probe can only remain on the motor for the duration of the measurement, its precision reinstallation must be solved for the successive measurements. The design and construction of a special probe holder to ensure this was the most delicate element of this program. In the first part of our paper we also show the results of a test performed with the confocal Omron ZW$S 40$ probe. During the test (with 50 thousand starts) the device worked flawlessly. Based on many (at least one hundred) post-reinstallation position measurements we state that the guaranteed reinstallation precision is 2-3 $\mu \mathrm{m}$, and the error caused by temperature uncertainties can be kept below $5 \mu \mathrm{m}$ (during measurements in the planned time frame).
\end{abstract}

Keywords: starter motor test, brush wear, confocal distance sensor method 


\section{Bevezetés}

Az indítómotorok tartóssági tesztjének fontos eleme a kefekopás ellenőrzése. Egy tipikus indítómotor szénkefe rendszerét ( $6 \mathrm{db}$ szénkefe), valamint egy szétszerelt szénkefét az 1. ábrán láthatunk. A kefekopást jelenleg az indítómotor házán a kefe fölött kifúrt lyukon keresztül (2. ábra) kézi mechanikai módszerrel mérik. A méréshez segédeszközként egy mérőtüskét használnak, amelyet az indítómotor házán fúrt - és egyúttal a szénkefe házán keresztül is haladó - furaton keresztül betolnak a szénkeféig (a rúgó csavarvonalának tengelye mentén) és a hosszát egy csavarral rögzítik. Ezt követően a kihúzott mérótüske hosszát tolómérővel megmérik.
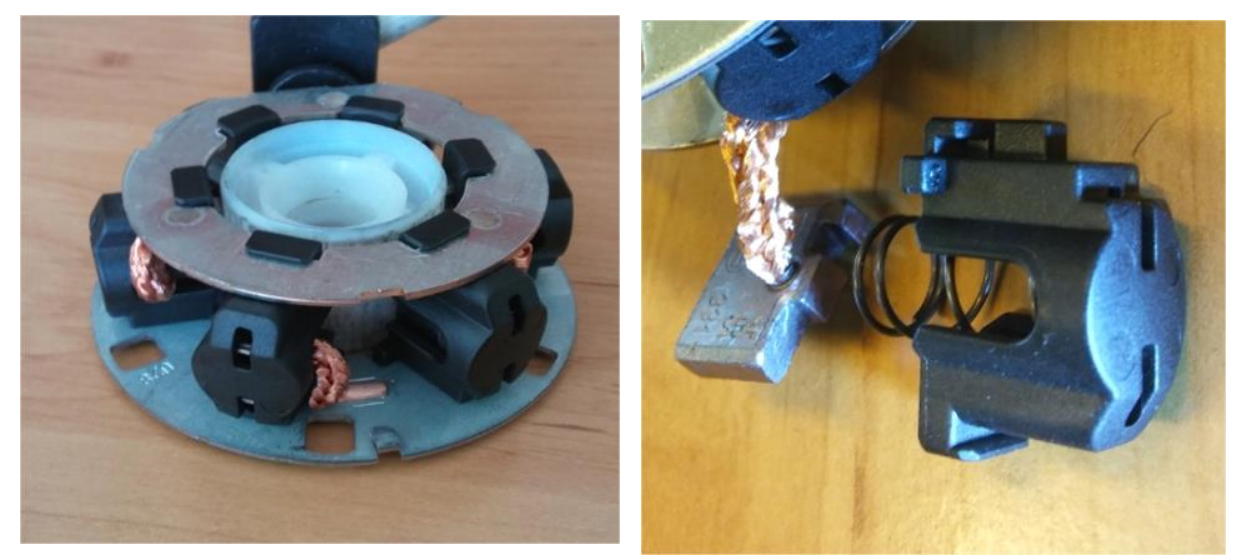

1. ábra. Az inditómotor szénkefe rendszere (bal oldalt), valamint egy szétszerelt szénkefe (jobb oldalt)

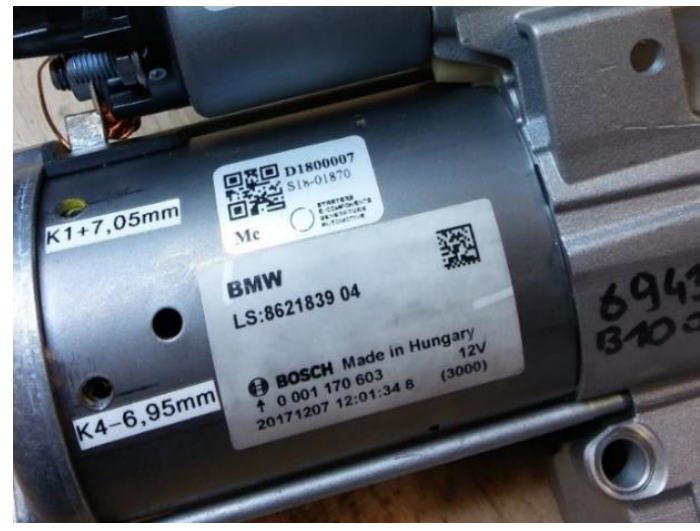

\section{2. ábra. A tesztelt inditómotor, a házán a kefék fölött kifúrt lyukakkal}

A tolómérös módszer pontossági határa - a tapasztalatok szerint - valahol 0,1-0,2 mm (100-200 $\mu \mathrm{m})$ között van. Hibafaktorok: leolvasási hiba $(0,05 \mathrm{~mm})$, a mérőtüske pozíciója az egymást követő mérések során nem reprodukálható pontosan, a mérés közben alkalmazott nyomóerők nagysága jelentősen különbözhet. Néhány napos teszt a tesztpadon kb. ekkora kefekopást eredményez, tehát a heti kefekopás mérések meglehetősen nagy relatív hibával terheltek. E hiba csökkentése jelentősen javíthatná a tartóssági tesztek hatékonyságát. 


\section{A mérési feladat megoldására alkalmas módszer kiválasztása}

A mérési hiba csökkentésének kézenfekvő módja a lézeres (vagy más kontaktusmentes optikai) méréstechnikára való áttérés, amellyel a kefekopás a jelenleginél lényegesen nagyobb pontossággal (legalább $10 \mu \mathrm{m}$ pontossággal) mérhető. Mint fentebb is utaltunk rá, a mérésre igen kis hely áll rendelkezésre a tesztpadon, magát a mérést az indítómotor házán a kefe fölött kifúrt lyukon keresztül kell elvégezni. Másik fontos körülmény, hogy a teszt során igen nagy mechanikai igénybevétel van (pl. a kapcsolások során nagy pillanatnyi gyorsulások), ami az állandóan, a teszt során is bennmaradó eszközöket kizárja.

A legszélesebb körben használt lézeres távolságmérök müködése a rövid lézerimpulzusok repülési idejének $(\mathrm{TOF}=$ time of flight) mérésén alapul [1-2]. Ezekben a kompakt müszerekben az elérhető időfelbontás jelenleg a pikoszekundum $\left(1 \mathrm{ps}=10^{-12} \mathrm{~s}\right)$ tartományba esik, az ennek megfelelő távolságmérési pontosság pedig $\mathrm{kb} .1 \mathrm{~mm}$. Ez még a tolómérők pontosságát sem éri el, a megkívánt $10 \mu \mathrm{m}$ pontosságtól pedig két nagyságrend választja el. (Megjegyezzük, hogy laboratóriumi körülmények között már a femtoszekundumos $\left(1 \mathrm{fs}=10^{-15} \mathrm{~s}\right)$ időfelbontás és az ennek megfelelő $1 \mu \mathrm{m}$-es távolságmérési pontosság is elérhető. Ez pedig előbb-utóbb meg fog jelenni a kompakt kézi müszerekben is.)

A pontossági spektrum másik szélén a lézerinterferometrikus mozgásanalizátorok állnak [3]. Ezek pontossága $(0,1 \mu \mathrm{m})$ megfelelő lenne, sőt az két nagyságrenddel meg is haladja az itt megkívántat. Ám azok nagy méretủek, rezgésmentes környezetet igényelnek. Felhasználásuk ebben a mérési feladatban reménytelennek látszik.

A lézeres távolságmérés kategóriába tartozó módszerek közül kétféle módszer jöhet itt ténylegesen számításba. A jelenlegi furat-geometriában a konfokális távolságérzékelés kínálja a legegyszerübb megoldást. Ez a módszer szigorúan véve nem lézeres módszer (mert fehér fényü fényforrást használ), de rendelkezik a kontaktusmentes lézeres módszerek minden előnyével. A módszer a lencsék színi hibáját is eredményező diszperzión alapul, ami miatt a fehér fényforrás fényét egy lencserendszer a hullámhossz függvényében más-más fókuszponttal fókuszálja. Ebben az alkalmazásban kimondottan a nagy színi hibájú (nagy kromatikus aberráció) leképezés a cél, amit nagy diszperziójú üvegből készült lencsével érhetünk el. A konfokális távolságérzékelők elvi felépítését a 3. ábra mutatja.

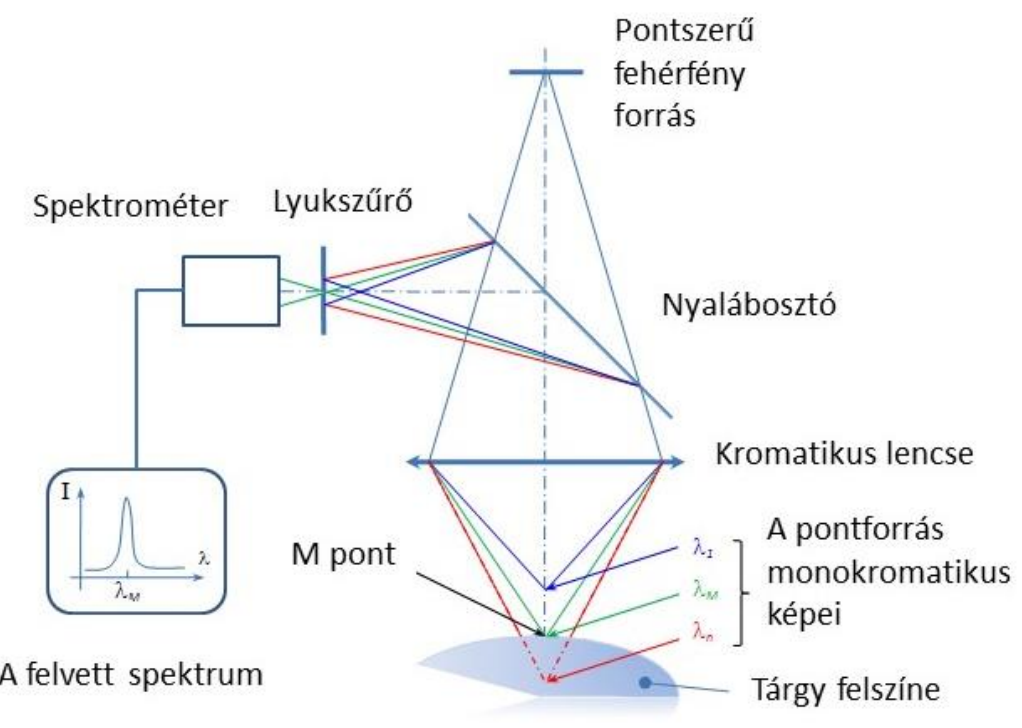

3. ábra. A konfokális távolságérzékelök elvi felépitése 
A pontszerü fehérfény forrás fényét a nagy kromatikus aberrációjú lencserendszer a mérendő tárgy felszínére fókuszálja. Természetesen csak egyetlen színi komponens lesz, amelynek a fókusza pont a tárgy felületére esik (az ábrán ez a középső - színesben zöld - komponens). A céltárgy által visszavert fény visszafelé is áthalad a lencserendszeren, tehát a zöld komponens pontosan a pontszerü fényforrásra fókuszálná. Ezt megelőzően azonban a visszavert fényt egy nyalábosztóval eltérítjük, így a fókuszpont egy lyukszürőre kerül. Ha a lyuk helyét és átmérőjét jól választjuk meg, akkor a fókuszált fény (az ábrán a zöld fény) teljes egészében átjut rajta, míg a többi szín csak töredékesen. Ha a távolság változik, akkor egy másik szín fókusza esik a tárgyra, és visszaverődés után ennek a színnek a fókusza esik a lyukszürő lyukára és ez detektálódik. A vevőbe jutó fény hullámhosszát megállapítva következtethetünk az érzékelő és a céltárgy távolságára. A müszer tehát egy jó minőségü optikai spektrométert is tartalmaz. A lencserendszert és lyukszürőt tartalmazó mérőfej száloptikával kapcsolódik a távolabb lévő alapmüszerhez (amely a jó minőségü optikai spektrométert is tartalmazza).

Az adott mérési feladat a lézeres háromszögelési módszerrel is megoldható azonban, ha a mérési geometriát kissé átalakítjuk (nagyobb átmérőjü vagy más alakú mérőlyukat fúrunk). A módszer vázlata az 4. ábrán látható. A fókuszált lézernyaláb a céltárgyra esik. Ezt a fénypontot az optika egy helyzetérzékeny detektorra (pl. CCD panel) képezi le. A képpont helyzete és a céltárgy távolsága egyértelmü kapcsolatban van egymással. Az ábrából rögtön kiolvasható a módszer hátránya is: a lézernyaláb beesési iránya és a mérési irány szöget zár be egymással. A jelenlegi geometriában, amikor egyetlen furat van az indítómotor házán, ez a mérés nem végezhető el. A geometria átalakításával (nagyobb átméröjü furat vagy furat helyett egy hosszabb rés) azonban ez a módszer is alkalmassá tehető.

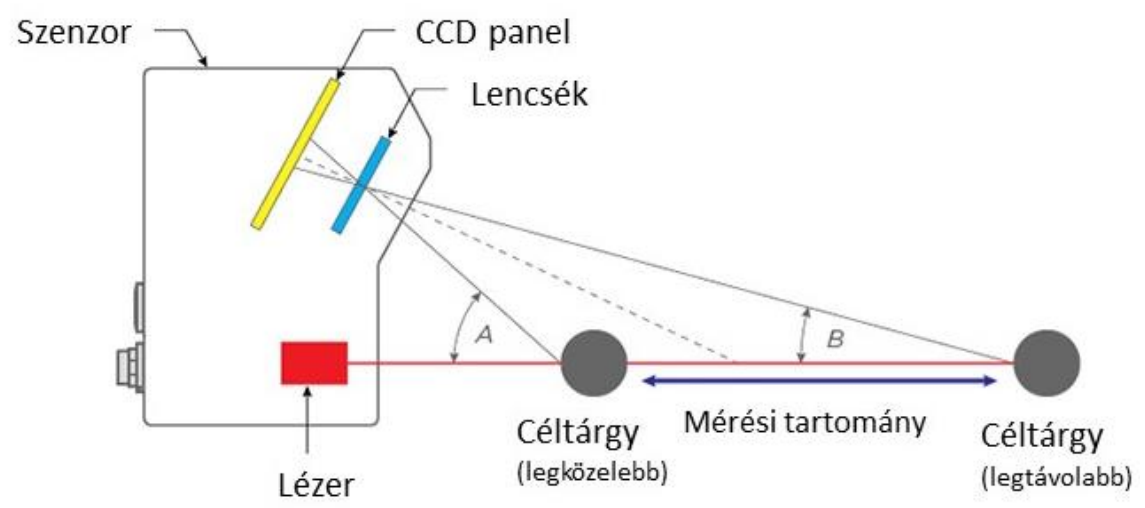

\section{4. ábra. A lézeres háromszögeléses módszer}

Részletesen elemeztünk négyféle, e módszerekhez tartozó mérőfejet. Közülük 3 db Omron gyártmány: ZW-S40 konfokális mérőfejéhez kétféle kivitelben (egyenes ill. pipa alakú), valamint a ZSHLDS5T típusú lézeres háromszögeléses mérőfej. A 4. mérőfej Keyence gyártmány: lézeres háromszögeléses IL-S025-ös mérőfej. A 4 mérőfej legfontosabb adatait az 1. táblázatban foglaltuk össze (a ZWS40 mérőfej kétféle kivitelének ugyanazok a paraméterei). Bár nincs a táblázatban, mégis igen fontos (a rendelkezésre álló hely szükössége miatt) a mérőfejek alakja, mérete is, azonban ezt egyetlen paraméterrel nem lehet jellemezni. Igen sokféle indítómotor van, valószínüleg egyik méröfej sem fog hozzáférni minden szénkeféhez. Például az Omron ZS-HLDS5T mérőfeje lényegesen pontosabb, mint a Keyence IL-S025, de ez utóbbi kisebb, több pozícióban használható, ezért a cég valószínüleg ezt fogja preferálni a háromszögeléses módszerek közül. 
1. táblázat. A méröfejek legfontosabb adatai [4,5]

\begin{tabular}{|l|l|l|l|l|l|l|}
\hline Módszer & Mérőfej & $\begin{array}{l}\text { Kezdő } \\
\text { távols. }\end{array}$ & $\begin{array}{l}\text { Mérh. } \\
\text { kopás }\end{array}$ & $\begin{array}{l}\text { Elvi pon- } \\
\text { tosság }\end{array}$ & $\begin{array}{l}\text { Hőmérs. té- } \\
\text { nyező }\end{array}$ & $\begin{array}{l}\text { Min. lyuk- } \\
\text { átm. }\end{array}$ \\
\hline Konfokális & $\begin{array}{l}\text { Omron } \\
\text { ZW-S40 }\end{array}$ & $34 \mathrm{~mm}$ & $12 \mathrm{~mm}$ & $1 \mu \mathrm{m}$ & $4,8 \mu \mathrm{m} /{ }^{\circ} \mathrm{C}$ & $6 \mathrm{~mm}$ \\
\hline $\begin{array}{l}\text { Lézeres há- } \\
\text { romsz. }\end{array}$ & $\begin{array}{l}\text { Omron ZS- } \\
\text { HLDS5T }\end{array}$ & $45 \mathrm{~mm}$ & $10 \mathrm{~mm}$ & $0,25 \mu \mathrm{m}$ & $1,0 \mu \mathrm{m} /{ }^{\circ} \mathrm{C}$ & $10 \mathrm{~mm}$ \\
\hline $\begin{array}{l}\text { Lézeres há- } \\
\text { romsz. }\end{array}$ & $\begin{array}{l}\text { Keyence } \\
\text { IL-S025 }\end{array}$ & $20 \mathrm{~mm}$ & $10 \mathrm{~mm}$ & $1 \mu \mathrm{m}$ & $3,0 \mu \mathrm{m} /{ }^{\circ} \mathrm{C}$ & $10 \mathrm{~mm}$ \\
\hline
\end{tabular}

Ahogy korábban is utaltunk rá, a konfokális müszerek nagy előnye az, hogy kis nyílásszögben mérnek, a mérés a jelenlegi furat-geometriában is elvégezhető. A lézeres háromszögelési módszer nagyobb átmérőjü vagy más alakú mérőlyukat igényel, ami mindenképpen egy nehézség. Cserébe viszont kisebb a hőmérsékleti tényezőjük, ami lehet, hogy fontos kérdés. Nem lehet tudni ugyanis, hogy az egymást követő mérések során (amelyek kb. hetente követik egymást) mekkorák pontosan a hömérséklet különbségek. A különböző mérőfejek üzemi körülmények közötti viselkedése (pl. a szénkefére rakódó szénpor, a rázkódások hatása, stb.) a rendelkezésre álló adatokból nem prognosztizálható pontosan. Valószínúleg csak több mérőfej együttes alkalmazásával lehet elérni azt, hogy minden típusú vizsgált indítómotor minden szénkeféjéhez hozzáférjen a mérés.

\section{A speciális rögzítő elem}

A mérőfej csak a mérés néhány másodperces (perces) idejére lehet az indítómotoron, annak kikapcsolt állapotában. Ugyanis sok szénkefét kell egyidejüleg (adott időközönként) mérni, másrészt a mérőfej nem bírná ki az indítómotor teszt közbeni rázkódásait. A mérés elvi pontossága kb. $1 \mu \mathrm{m}$. Ezt a pontosságot akkor tudnánk maradéktalanul kihasználni, ha a visszahelyezés pontossága is elérné az $1 \mu \mathrm{m}$ t. Ehhez mindenképpen egy speciális rögzítő elem szükséges, amely a mérőfejet rögzíti az indítómotor háza külső felületéhez. Ez a speciális rögzítő elem távtartást is végez, azaz a lyuk közepétől adott távolságra (a ZW-S40 mérőfej esetén 28 mm-re) tartja a mérőfejet.

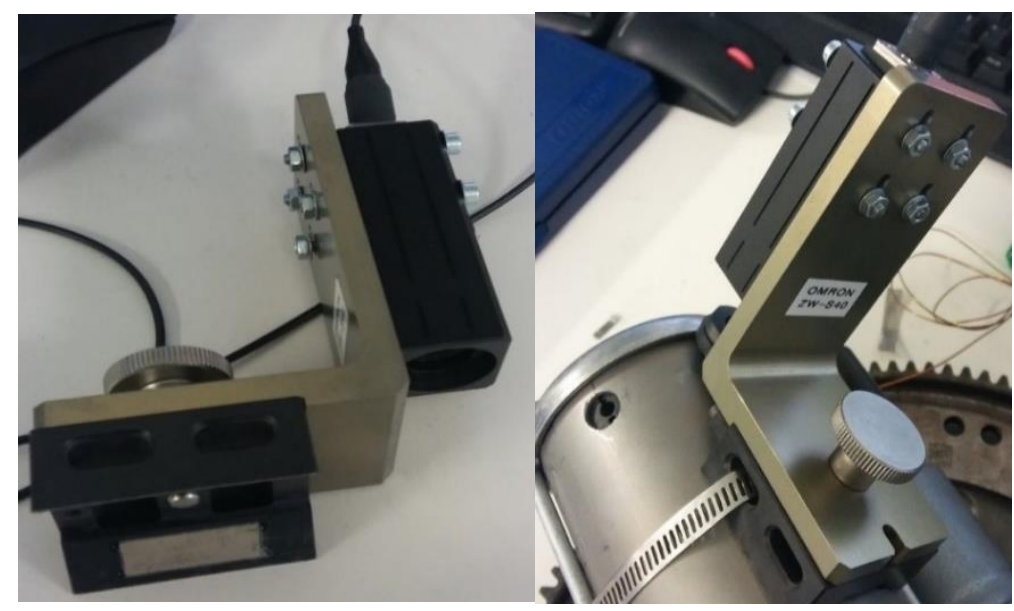

5. ábra. A ZW-S40 méröfejhez legyártott speciális rögzitö elem a rárögzített méröfejjel felszerelés elött (balra), ill az inditómotorra rögzitve (jobbra) 
A mérőfejjel egybeépített speciális rögzítő elem felhelyezését és leszedését tehát néhány mozdulattal, néhány másodperc alatt meg kell oldani. Ilyen típusú kötést mágnesek segítségével lehet megoldani (az indítómotor háza ferromágneses anyagból van). A speciális rögzítő elem két részből áll, egy alaplapból és a hozzá precíziós módon illeszkedő mérőfej tartóból, a kötést kézzel oldható csavar rögzíti.

Az egyik részt (fekete színủ alaplap) a megfelelő pozícióban két mágnes rögzíti az indítómotorhoz. Ez a mágneses kötés elég erős, de a kapcsolások közbeni nagy rángások esetleg mégis elmozdíthatják. Ezért ezt a kötést rögzítő szalagokkal is megerösítettük.

A speciális rögzítő elem másik részéhez (világos színű mérőfej tartó) a mérőfejet 4 csavarral kell rögzíteni. Itt nagyon kell figyelni a mérőfej optikájának a kezdő távolságára.

Kritikus, hogy a mérőfej visszarakása az újbóli méréshez igen pontos legyen. Az első próbák során a rögzítő elem alaplapjára a mérőfej tartó pontatlanul és pontosan is visszarakható volt. Kellő odafigyeléssel a visszarakási pontosság 2-3 $\mu \mathrm{m}$ volt ugyan, de a nem kellő figyelemmel történt visszarakás akár 100-200 $\mu \mathrm{m}$ hibát is okozhatott. Éles mérések esetén ez a pontatlansági kockázat nyilvánvalóan nem fogadható el, mert a méréseket többnyire nem magasan kvalifikált szakemberek végzik.

Szerencsére ezt a pontatlansági kockázatot egy második stift hozzáadásával viszonylag könnyen meg tudtuk szüntetni. Ennél a megoldásnál a 2-3 $\mu \mathrm{m}$-es visszarakási pontosság már könnyen tartható volt. Ez a pontosság a tervezett mérésekhez tökéletesen megfelel, vagyis a javított speciális rögzítőelem tökéletesen müködik.

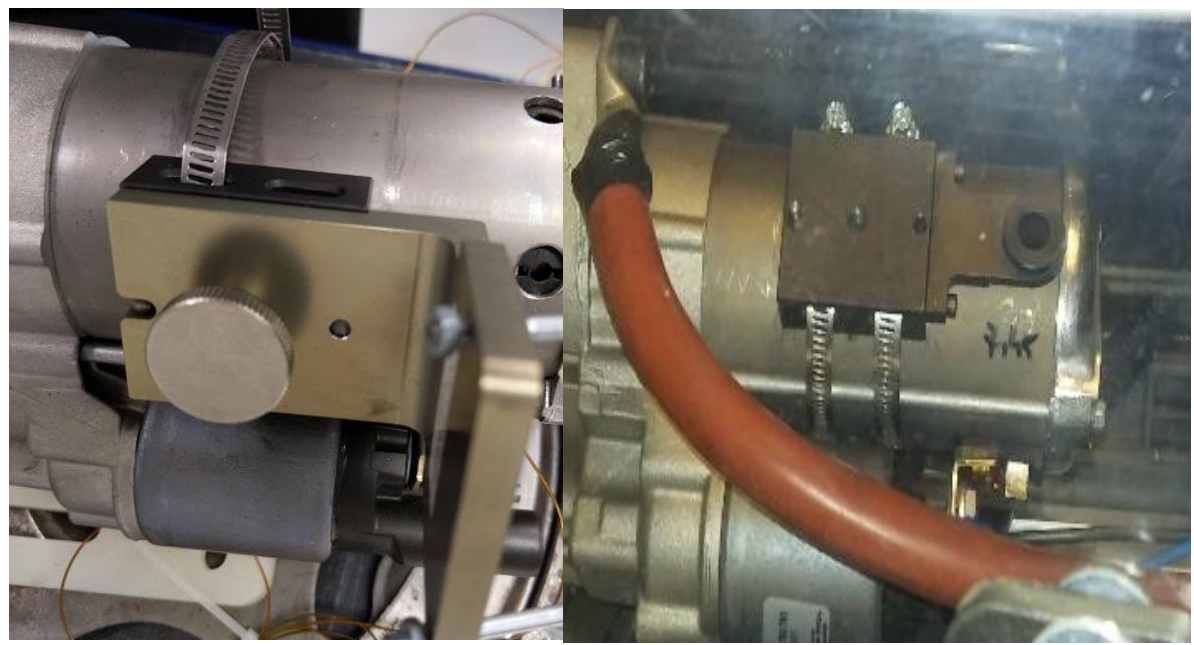

6. ábra. A javitott speciális rögzitö elem. A bal oldali ábrán a második stift a kézzel oldható rögzitö csavartól jobbra látható és a jobb oldali ábrán a rögzitö elem alaplapján is jól megfigyelhetö

\section{Az OMRON ZW-S40 konfokális mérőfej tesztelése}

A konfokális mérőfej tesztelésére egy külön mérőkamrát kellett létrehozni (ugyanis az „éles” tesztelö helyek $100 \%$-ban foglaltak voltak a legyártott önindítók tesztelésével). Ez a mérőhely (7. ábra) abban hasonlít az „élesekhez”, hogy az indításokat előre programozott módon automatikusan elvégzi.

Abban viszont különbözik (de nagyon), hogy itt az indítómotornak nincs mechanikai terhelése, ezáltal lényegesen kisebb az áramfelvétele (ez pedig nyilvánvalóan kisebb kefekopást jelent). 


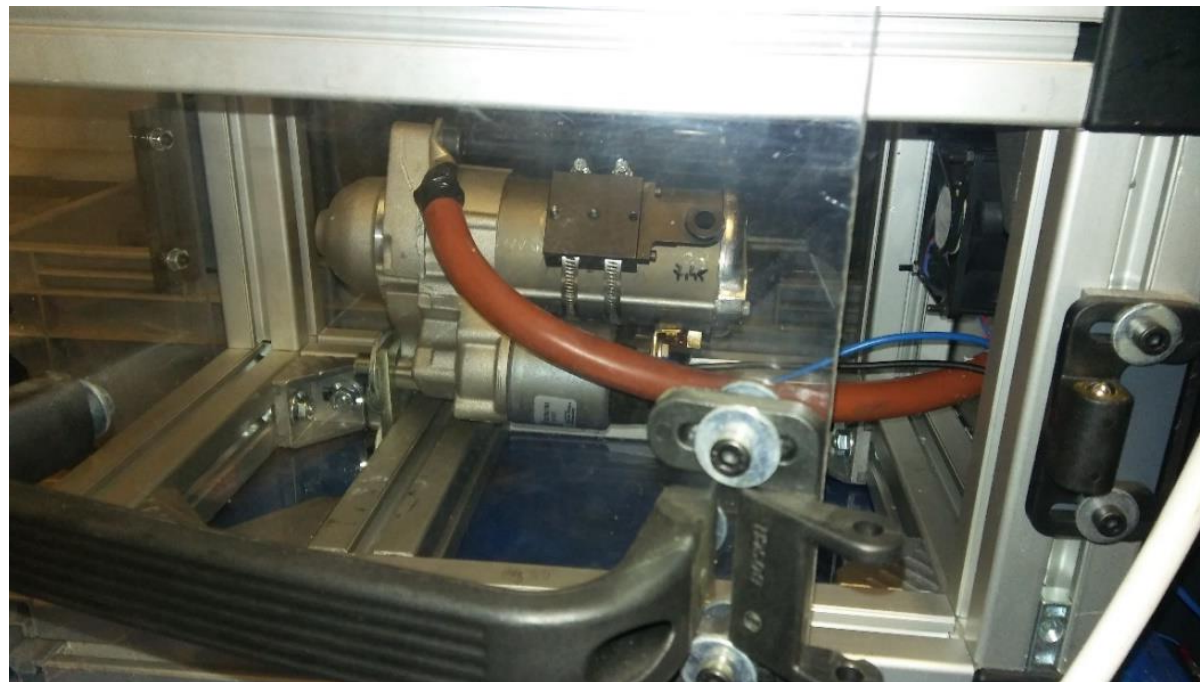

7. ábra. A konfokális méröfej tesztelésére kialakitott mérökamra. A fényképen jól látható a speciális rögzítöelem indítómotorhoz kötött része (a méröfej most éppen nincs felhelyezve).

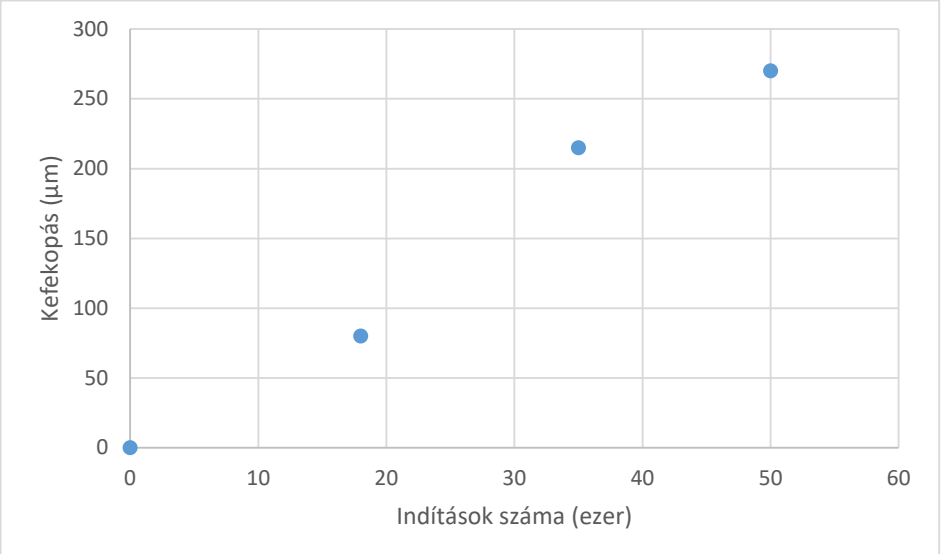

8. ábra. A kefekopás az inditások számának függvényében. (A teszt során az inditómotor nem volt terhelve.)

Összesen 50 ezer indítást végeztünk. Egy indítás 0,9 másodpercig tartott, az indítások 25 másodpercenként követték egymást. Ez jelentős hőterhelést jelentett a kamrában, a túlmelegedés elkerülése érdekében a kamrába egy ventilátor is beépítésre került.

A müszer a következő y távolság adatokat mérte (a tényleges távolság a mérőfej optikája és a szénkefe teteje között 40-y [mm]): kezdetben $\mathrm{y}=4,860 \mathrm{~mm} ; 18$ ezer indítás után $\mathrm{y}=4,780 \mathrm{~mm}$; 35 ezer indítás után $\mathrm{y}=4,645 \mathrm{~mm} ; 50$ ezer indítás után $\mathrm{y}=4,59 \mathrm{~mm}$. Tehát végeredményben a szénkefe kopása az 50 ezer indítás alatt összesen $0,270 \mathrm{~mm}$ volt. A kefekopás adatokat a 7 . ábrán is bemutatjuk.

Külön megfontolást igényel a kefekopás adatok hibája. A mérőfej elvi pontossága $1 \mu \mathrm{m}$ (1. táblázat). Ennél sajnos nagyobb hibával rakható vissza a mérőfej a következő méréshez. Igen sok (legalább száz) visszarakást követő pozíció mérés alapján állítjuk, hogy a garantált visszarakási pontosság 2-3 $\mu \mathrm{m}$ körül 
van. A hőmérsékleti bizonytalanságok valószínűleg ennél is nagyobb mérési hibát okoznak. Ahogy fentebb is említettük, az indítások megnövelik a tesztkamrában a hőmérsékletet. A kefekopás mérés alatt az indítások szünetelnek, tehát a tesztkamra hül. Mindeközben a felhelyezett mérőfej lassan felveszi az indítómotor (egyre csökkenő) hőmérsékletét. Hőtágulása a mérőrendszer minden elemének van, nemcsak a mérőfejnek, hanem a speciális tartónak, a motor házának, a szénkefének is. A kefekopás mért értéke nyilván függeni fog a hőmérsékletek eloszlásától, vagyis attól, hogy a mérés mennyi idő múlva követi az indítások leállítását. Ez a függést előre kiszámítani szinte lehetetlen, a különböző elemek hötágulása szerencsére ellentétes hatású is lehet. Például a speciális tartó hülése csökkenti a mért távolság értéket, a szénkefe és a mérőfej hülése viszont növeli. A tapasztalataink szerint a mérőfej felhelyezését követő percekben valóban változik a mért távolság, de ez $5 \mu \mathrm{m}$ alatt marad. A továbbiakban ezt az $5 \mu \mathrm{m}$ t tekintjük a hőmérsékleti bizonytalanságok által okozott hibának, feltéve, hogy a mérés a tervezett módon történt. Tehát a mérőfej a mérés előtt is a laborban volt, felvette annak hőmérsékletét, csak a felhelyezéshez szükséges ideig tartottuk a kezünkben, a felhelyezés után pár percen belül elvégeztük a mérést, stb. Mindezen hibákat figyelembe véve garantálható, hogy a mérés teljes hibája nem haladja meg a $10 \mu \mathrm{m}$-t. A 8 . ábrán ez azt jelenti, hogy a mérési hiba kb. a mérési adatot ábrázoló pont méretének felel meg.

\section{5. Összefoglalás, következtetések}

A jelen cikkben a kefekopás mérési módszer pontosításának tervezésére, egy optikai mérési koncepció kidolgozására koncentráltunk. A lehetőségek felmérésénél az alábbi szempontokat kellett figyelembe venni:

a, a mérésre igen kis hely áll rendelkezésre (sőt a mérést lényegében egyetlen furaton keresztül kell elvégezni);

b, a tesztpadon igen nagy mechanikai igénybevétel van (pl. a kapcsolások során nagy pillanatnyi gyorsulások lépnek fel), ami kizárja a mérés után is ott maradó eszközöket;

c, a megkívánt pontosság - minden hibaforrást figyelembe véve - legalább $10 \mu \mathrm{m}$.

Mindezeket figyelembe véve első helyen a konfokális távolságérzékelők alkalmazását, második helyen a lézeres háromszögelési módszer alkalmazását javasoljuk. A konfokális módszert az teszi az első helyre, hogy a mérés a jelenlegi furat-geometriában is elvégezhető. A lézeres háromszögelési módszer viszont nagyobb átmérőjü vagy más alakú mérőlyukat igényel, Mindkét módszerhez szükséges egy speciális mérőfej tartó megtervezése és legyártása.

A tesztek során megerősödött a véleményünk a konfokális módszer alkalmazhatóságáról. Az Omron ZW-S40 mérőfejjel hosszú (50 ezer indításos) tesztet is sikerült elvégezni, a teszt során az eszköz hibátlanul müködött.

Tapasztalataink szerint az elkészített speciális mérőfej tartóval a garantált visszarakási pontosság 2-3 $\mu \mathrm{m}$, a hőmérsékleti bizonytalanságok által okozott hiba $5 \mu \mathrm{m}$ alatt tartható (tervezett időkeretben történő mérés során). Egyéb lényeges hibaforrás a mérések során nem merült fel, tehát az eredetileg is tervezett $10 \mu \mathrm{m}$-es kefekopás mérési pontosság ezzel az eszközzel tartható.

Eltekintve a nagyobb mérőlyuk problémájától a lézeres háromszögelési módszer is alkalmas lehet a mérési feladat végrehajtására. Bizonyos tekintetekben (hőmérsékleti tényező, porosodásra érzékenység, ár, stb.) talán még kedvezőbb is lehet, mint az ebben a cikkben részletesebben vizsgált konfokális módszer. A területen tapasztalható lendületes fejlődés, a piacon megjelenő új mérőfejek is gyorsan átírhatják a preferenciákat. Cikkünk második részében ezzel fogunk foglalkozni. 


\section{Köszönetnyilvánítás}

A kutató munka az Európai Unió és a magyar állam támogatásával, az Európai Regionális Fejlesztési Alap társfinanszírozásával, a GINOP-2.3.4-15-2016-00004 projekt keretében valósult meg, a felsőoktatás és az ipar együttmüködésének elősegítése céljából.

Köszönjük Vajas Lászlónak, az Euro-Eng Kft. munkatársának a speciális mérőfej tartó megtervezése során történő hasznos konzultációkat, a tervek elkészítését és az eszköz legyártását.

Köszönjük továbbá Sauer Géza villamosmérnöknek az Omron Electronics Kft. munkatársának a cikkben szereplő mérőeszköznek mérések idejére történő kölcsönadását.

\section{Irodalom}

[1] Berkovic, G., Shafir, E.: Optical methods for distance and displacement measurements, Advances in Optics and Photonics 4. 441. (2012) https://doi.org/10.1364/AOP.4.000441

[2] Soo Suh, Y.: Laser Sensors for displacement, distance and position, Sensors 191924 (2019) https://doi.org/10.3390/s19081924

[3] Béres, M., Majár, J., Rónai, L., Paripás, B.: Preciziós sebességmérés lézerinterferometrikus módszerrel, Miskolci Egyetem Közleményei Multidiszciplináris Tudományok, 6. kötet. (2016) 1 sz. pp. 9-19.

[4] Keyence CMOS Multi-Function Analog Laser Sensor, https://www.keyence.com/products/measure/laser-1d/il/?search_sl=1

[5] Omron ZW Series, https://industrial.omron.hu/hu/products/zw-series 